IJ§ER

ISSN: 2149-5939
International Journal of Social Sciences and Education Research

Online, http://dergipark.gov.tr/ijsser

Volume: 4(4), 2018

\title{
Authentic leadership and follower job satisfaction: The moderating effect of leader emotional expressivity
}

\author{
Nevra Baker ${ }^{1}$
}

Submission date: 24 / 07 / 2018

Accepted date: $08 / 10 / 2018$

\begin{abstract}
This research attempts to explain the moderating effect of leader emotional expressivity on the relationship between authentic leadership and follower job satisfaction. Accordingly, quantitative data, collected via survey administration to front-line employees of service-rendering companies from Istanbul was used to test the hypotheses. The findings of this study revealed that the strength of leader emotional expressivity weakened the positive contributions of authentic leadership to follower job satisfaction for leaders who demonstrate a high level of authentic leadership. On the other hand, higher leader emotional expressivity compensates for the low levels of authentic leadership in terms of increasing follower job satisfaction.
\end{abstract}

Keywords: Leadership, emotions, authentic leadership, leader emotional expressivity, follower job satisfaction

\section{Introduction}

Authentic leadership is one of the most widely researched theories in leadership. The creators of this construct assert that the decline in ethical leadership (e.g., WorldCom, Enron, Martha Stewart) together with a rise in societal troubles (e.g., September 11 terrorism, fluctuating stock values, a downturn in the economy) entails the need for authentic leadership more than in earlier times (Cooper et al., 2005). They also discuss that present frameworks are not adequate for training leaders of the future (Avolio \& Gardner, 2005). Antecedents and outcomes of authentic leadership have been explored by several researchers (e.g., Luthans and Avolio, 2003; Gardner et al., 2005; Sparrowe, 2005; Shamir and Eilam, 2005). According to Bennis (2003) and Eriksen (2009); self-knowledge is a prerequisite for authentic leadership. Shamir and Eilam (2005) cite that leaders who have a high level of self-knowledge are clear about their values and convictions. Another antecedent for authentic leadership is self-consistency (Peus et al., 2012). Walumbwa et al. (2008) argue that it is of utmost importance for leaders to show consistency between their values, beliefs, and actions in order to be perceived as authentic.

Emotions are omnipresent in leader-follower interactions, originating from and also affecting them (Rubin, Munz, \& Bommer, 2005; Sy, Côté, \& Saavedra, 2005). Because leaders have a deep influence on the activity of organizations and their insiders (Yukl, 2005), leader emotional expositions have solid capacity to affect how their subordinates feel, think, and act (George, 2000).

${ }^{1}$ Asst. Prof, Altinbas University, Istanbul/TURKEY, nevra.baker@altinbas.edu.tr 
Baker, N. (2018). Authentic leadership and follower job satisfaction: The moderating effect of leader emotional expressivity. International Journal of Social Sciences and Education Research, 4(4), 689-697.

In this study, the contribution of authentic leadership to the follower job outcomes of job satisfaction, as well as the moderating effect of leader emotional expressivity on the relationship between the two concepts were analyzed.

\section{Literature review}

\subsection{Authentic leadership and follower job satisfaction}

Job satisfaction has been portrayed as a "pleasurable or positive emotional state resulting from the appraisal of one's job or job experiences" (Locke, 1976, p. 1304). Theory puts forward that authentic leadership should have a positive relation to job satisfaction (Gardner, Avolio, Luthans, et al., 2005). For instance, Ilies et al. (2005) announced that authentic leaders potentially have a favorable effect on followers' behaviors in that this kind of leaders makes sure that followers' self-determination is encouraged. Also, research has indicated that such leaders are more effective at breeding intrinsic employee motivation (Deci, Connell, \& Ryan, 1989). By increasing their self-determination and motivation, we put forth that authentic leaders will contribute to their followers' positive job experiences, which will result in greater follower job satisfaction.

The study by Gezer (2015) in the Turkish context found a significant positive relationship between each of the components of authentic leadership, that are relational transparency, internalized moral perspective, balanced processing, and self-awareness, and follower job satisfaction. Also, the study by Ayça (2016) in the Turkish tourism sector revealed that job satisfaction is an outcome of authentic leadership. Thus, we came up with the following hypothesis:

H1: Authentic leadership will have a positive contribution to follower job satisfaction.

\subsection{The moderating effect of leader emotional expressivity on the relationship between authentic leadership and follower job satisfaction}

Locke (1976) defined job satisfaction as a "pleasurable or positive emotional state resulting from the appraisal of one's job or job experiences" (p. 1304). According to us, emotions are a great way to show how one appraises another's deeds. For example, if a leader shows contentedness towards a follower right after his or her action, the follower will think that this action made the leader happy. Or, vice versa, if an expression of anger by the leader follows a follower's action, the follower will think that something is wrong with what he or she has just done. On the other hand, followers of leaders who generally act neutral will not know what their leader feels about how they are doing, and therefore will not be able to get the necessary appraisal from their leaders, which is a prerequisite for job satisfaction, according to Locke's definition. Thus, we come up with the suggestion that in case of leaders who are lower in authenticity, a stronger leader emotional expressivity will compensate for the lack of authenticity, and increase the perceptions of the followers as being appraised by their leaders, which will contribute positively to their job satisfaction. In contrast, for leaders who are already highly authentic, a strong leader emotional expressivity will be perceived by followers as the leader is expressing an overly-possessive leadership and as the leader is crossing a boundary when interacting with followers.

In sum, we expect that leader emotional expressivity (LEE) will compensate for the negative implications of low leader authenticity by encouraging follower job satisfaction. If a leader lacks authenticity, and if this leader demonstrates a high level of leader emotional expressivity, then this high level of leader emotional expressivity will compensate for the lack of authentic leadership by increasing follower job satisfaction. On the other hand, if a leader is already strongly 
Baker, N. (2018). Authentic leadership and follower job satisfaction: The moderating effect of leader emotional expressivity. International Journal of Social Sciences and Education Research, 4(4), 689-697.

authentic, in this case, a high level of emotional expressivity by the same leader will be perceived by the followers of this leader as intimidating and they will feel that their leader is crossing a boundary when interacting with them. Therefore, followers' job satisfaction will again increase, however less strongly as compared to strongly authentic leaders who demonstrate a lower level of emotional expressivity. Namely, if strongly authentic leaders demonstrate a lower level of emotional expressivity, then there will be a more positive relationship between authentic leadership and follower job satisfaction, in comparison to leaders who demonstrate a higher level of emotional expressivity. In other words, if a strongly authentic leader does not express a very high level of emotional expressivity, then follower job satisfaction will increase more strongly with increasing leader authenticity.

Thus, we came up with the following hypothesis:

H2. The relationship between authentic leadership and follower job satisfaction will be moderated by leader emotional expressivity (LEE), in such a way that the relationship between authentic leadership and follower job satisfaction is more positive for those employees whose leaders are lower on LEE as compared to those whose leaders are higher on LEE.

\section{Methodology}

\subsection{Research design}

The aim of this study is to test the contribution of authentic leadership to follower job outcomes of job satisfaction. In addition, this study aims to test the moderating effect of the strength of leader emotional expressivity on the relationship between authentic leadership and follower job satisfaction.

The model depicting the hypothetical relationships is presented in Figure 1.

Figure 1. Conceptual model of the study

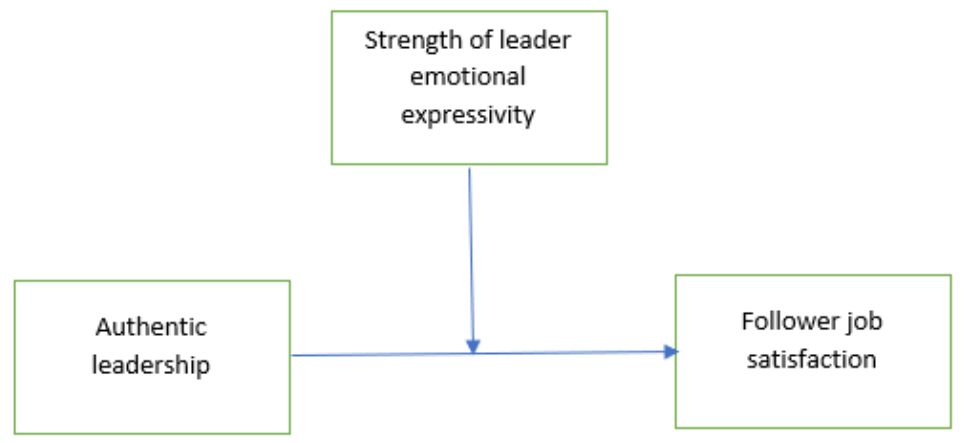

A survey was undertaken in order to test the hypotheses with the aim of testing both the contribution of authentic leadership to follower job satisfaction and finding out the moderating effect of the strength of leader emotional expressivity on the relationship between authentic leadership and follower job satisfaction. The participants were asked to rate their perception of the authenticity and emotional expressivity of their actual leaders, and then they were asked to rate their own actual level of job satisfaction. Authentic Leadership Inventory-ALI by Neider and Schriesheim (2011) and Emotional Expressivity Scale by Kring et al. (1994) were utilized for the participants to rate their actual leader. In addition, for the ratings of follower job satisfaction, the items of the shorter version of by Brayfield \& Rothe's (1951) job satisfaction scale, which was 
Baker, N. (2018). Authentic leadership and follower job satisfaction: The moderating effect of leader emotional expressivity. International Journal of Social Sciences and Education Research, 4(4), 689-697.

shortened to a five item scale by Judge, Locke, Durham, \& Kluger (1998) was used. The questions were read to the participants and their answers were recorded on a tablet PC.

\subsection{Sample}

A total of 258 employees working in the services departments from 32 firms and their immediate supervisors were contacted. The average age of the employees is 28.64 , ranging from 18 to $62.94(36.4 \%)$ of the contacted employees are female. $42(16.3 \%)$ of the contacted employees attended only elementary school, $160(62 \%)$ are high school graduates, $54(20.9 \%)$ attended university, and $2(0.8 \%)$ completed higher education. In contrast, $19(7.4 \%)$ of their immediate supervisors finished elementary school, 107 (41.5\%) graduated from high school, and 132 (51.2\%) are university graduates. The average working years add up to 8.20, ranging from 1 to 40 , and the average tenure is 3.69 years, ranging from a minimum of 1 to a maximum of 20 years. $90(34.9 \%)$ of the total of 258 respondents are from the retail industry, $49(19 \%)$ work in the food industry, $48(18.6 \%)$ come from the textile industry, $17(6.6 \%)$ work in the IT sector, $12(4.7 \%)$ are from the electronics industry, $10(3.9 \%)$ work in the financial industry, $8(3.1 \%)$ come from the construction industry, another $8(3.1 \%)$ work in the paper industry, and again another $8(3.1 \%)$ are hired in the agricultural industry, $6(2.3 \%)$ deal with trade, and lastly $2(0.8 \%)$ are employed in customer services.

\section{Findings of the study}

Regression analysis has been undertaken in order to test the contribution of authentic leadership to follower job satisfaction. For the regression analysis, two models have been created. The first model tests the effect of control variables on the dependent variable, and the second model tests the effect of the independent variables on the dependent variable, in addition to the effect of the control variables on the dependent variable.

For the measurement of the direct effect of authentic leadership on follower job satisfaction, the multiple regression models are expressed as follows:

Model 1: Follower job satisfaction $=\beta_{0}+\beta_{1} *($ Age $)+\beta_{2} *($ Gender $)+\beta_{3} *($ Tenure $)+\varepsilon$

Model 2: Follower job satisfaction $=\beta_{0}+\beta 1 *($ Age $)+\beta_{2} *($ Gender $)+\beta_{3} *($ Tenure $)+\beta_{4} *(\mathrm{Au}-$ thentic leadership) $+\varepsilon$

In these models; age, gender, and tenure are control variables.

The tables 1 and 2 below show the results of the multiple regression analysis:

Table 1. Model summary of the multiple regression analysis for the contribution of authentic leadership to follower job satisfaction

\begin{tabular}{|c|c|c|c|c|c|c|c|c|c|c|}
\hline \multicolumn{11}{|c|}{ Model Summary } \\
\hline \multirow{2}{*}{ Model } & \multirow[t]{2}{*}{$\mathrm{R}$} & \multirow[t]{2}{*}{$\mathrm{R}^{2}$} & \multirow{2}{*}{$\begin{array}{l}\text { Adj. } \\
\mathrm{R}^{2}\end{array}$} & \multirow{2}{*}{$\begin{array}{l}\text { Std. Error } \\
\text { of the Es- } \\
\text { timate }\end{array}$} & \multicolumn{5}{|c|}{ Change Statistics } & \multirow{2}{*}{$\begin{array}{l}\text { Durbin- } \\
\text { Watson }\end{array}$} \\
\hline & & & & & $\Delta \mathrm{R}^{2}$ & $\Delta \mathrm{F}$ & df1 & $\mathrm{df2}$ & Sig. $\Delta \mathrm{F}$ & \\
\hline 1 & .12 & .01 & .00 & .98 & .01 & 1.21 & 3 & 254 & .31 & \multirow[b]{2}{*}{2.11} \\
\hline 2 & .80 & .63 & .63 & .60 & .62 & 427.08 & 1 & 253 & .00 & \\
\hline
\end{tabular}


Baker, N. (2018). Authentic leadership and follower job satisfaction: The moderating effect of leader emotional expressivity. International Journal of Social Sciences and Education Research, 4(4), 689-697.

Table 2. Regression coefficients for the contribution of authentic leadership to follower job satisfaction

\begin{tabular}{|c|c|c|c|c|c|c|c|c|}
\hline \multirow[t]{2}{*}{ Model } & \multirow[t]{2}{*}{$\begin{array}{c}\text { Independent } \\
\text { Variables }\end{array}$} & \multicolumn{2}{|c|}{$\begin{array}{c}\text { Unstandardized } \\
\text { Coefficients }\end{array}$} & $\begin{array}{c}\text { Standardized } \\
\text { Coefficients }\end{array}$ & \multirow[t]{2}{*}{$\mathrm{t}$} & \multirow[t]{2}{*}{ Sig. } & \multicolumn{2}{|c|}{$\begin{array}{c}\text { Collinearity Sta- } \\
\text { tistics }\end{array}$} \\
\hline & & $\beta$ & $\begin{array}{l}\text { Std. Er- } \\
\text { ror }\end{array}$ & $\beta$ & & & Tolerance & VIF \\
\hline 1 & $\begin{array}{l}\text { (Constant) } \\
\text { Age } \\
\text { Gender } \\
\text { Tenure }\end{array}$ & $\begin{array}{c}4.01 \\
.00 \\
-.07 \\
-.03 \\
\end{array}$ & $\begin{array}{l}.34 \\
.01 \\
.13 \\
.03 \\
\end{array}$ & $\begin{array}{c}.00 \\
-.03 \\
-.11 \\
\end{array}$ & $\begin{array}{l}11.73 \\
-.00 \\
-.51 \\
-1.30 \\
\end{array}$ & $\begin{array}{l}.00 \\
1.00 \\
.61 \\
.19 \\
\end{array}$ & $\begin{array}{l}.54 \\
.99 \\
.54 \\
\end{array}$ & $\begin{array}{l}1.86 \\
1.01 \\
1.87 \\
\end{array}$ \\
\hline 2 & $\begin{array}{l}\text { (Constant) } \\
\text { Age } \\
\text { Gender } \\
\text { Tenure } \\
\text { Authentic } \\
\text { leadership }\end{array}$ & $\begin{array}{c}.15 \\
.01 \\
-.00 \\
-.01 \\
.90\end{array}$ & $\begin{array}{l}.28 \\
.01 \\
.08 \\
.02 \\
.04\end{array}$ & $\begin{array}{l}.05 \\
-.00 \\
-.04 \\
.80\end{array}$ & $\begin{array}{c}.54 \\
.93 \\
-.05 \\
-.73 \\
20.67\end{array}$ & $\begin{array}{l}.59 \\
.35 \\
.96 \\
.47 \\
.00\end{array}$ & $\begin{array}{l}.54 \\
.99 \\
.53 \\
.98\end{array}$ & $\begin{array}{l}1.86 \\
1.01 \\
1.87 \\
1.02\end{array}$ \\
\hline
\end{tabular}

According to the above tables, authentic leadership $(\beta=0.80, \mathrm{t}=20.67, \mathrm{p}<.05)$ significantly predicts job satisfaction. This model explains $63 \%$ of the variance $(\mathrm{p}<.05)$. Thus, the hypothesis H1 (Authentic leadership will have a positive contribution to follower job satisfaction) is supported.

The multiple regression models for the moderating effect of leader emotional expressivity (LEE) on the relationship between authentic leadership and follower job satisfaction are demonstrated as follows:

Model 1: Follower job satisfaction $=\beta_{0}+\beta_{1} *($ Age $)+\beta_{2} *($ Gender $)+\beta_{3} *($ Tenure $)+\varepsilon$

Model 2: Follower job satisfaction $=\beta_{0}+\beta 1 *($ Age $)+\beta_{2} *($ Gender $)+\beta_{3} *($ Tenure $)+\beta_{4} *(\mathrm{ZAu}-$ thentic leadership) $+\beta_{5} *$ (ZLEE) $+\varepsilon$

Model 3: Follower job satisfaction $=\beta_{0}+\beta_{1} *($ Age $)+\beta_{2} *($ Gender $)+\beta_{3} *($ Tenure $)+\beta_{4} *(\mathrm{ZAu}-$ thentic leadership $)+\beta_{5} *$ (ZLEE) $+\beta_{6} *$ (ZAuthentic leadership * ZLEE $)+\varepsilon$

In these models; age, gender, and tenure are control variables.

Table 3 and 4 below demonstrate the moderating effect of leader emotional expressivity (LEE) on the relationship between authentic leadership and follower job satisfaction.

Table 3. Model summary of the multiple regression analysis for the moderation of LEE on the relationship between authentic leadership and follower job satisfaction

\begin{tabular}{|c|c|c|c|c|c|c|c|c|c|c|}
\hline \multicolumn{11}{|c|}{ Model Summary } \\
\hline \multirow[t]{2}{*}{ Model } & \multirow[t]{2}{*}{$\mathrm{R}$} & \multirow[t]{2}{*}{$\mathrm{R}^{2}$} & \multirow{2}{*}{$\begin{array}{l}\text { Adj. } \\
R^{2}\end{array}$} & \multirow{2}{*}{$\begin{array}{l}\text { Std. Er- } \\
\text { ror of the } \\
\text { Estimate }\end{array}$} & \multicolumn{5}{|c|}{ Change Statistics } & \multirow{2}{*}{$\begin{array}{l}\text { Durbin- } \\
\text { Watson }\end{array}$} \\
\hline & & & & & $\Delta \mathrm{R}^{2}$ & $\Delta \mathrm{F}$ & df1 & $\mathrm{df} 2$ & Sig. $\Delta F$ & \\
\hline 1 & .12 & .01 & .00 & .98 & .01 & 1.21 & 3 & 254 & .31 & \multirow[b]{3}{*}{2.09} \\
\hline 2 & .81 & .65 & .64 & .59 & .64 & 216.48 & 2 & 252 & .00 & \\
\hline 3 & .81 & .65 & .64 & .59 & .01 & 9.75 & 1 & 251 & .00 & \\
\hline
\end{tabular}


Baker, N. (2018). Authentic leadership and follower job satisfaction: The moderating effect of leader emotional expressivity. International Journal of Social Sciences and Education Research, 4(4), 689-697.

Table 4. Regression coefficients for the moderation of LEE on the relationship between authentic leadership and follower job satisfaction

\begin{tabular}{|c|c|c|c|c|c|c|c|c|}
\hline \multirow[t]{2}{*}{ Model } & \multirow[t]{2}{*}{$\begin{array}{c}\text { Independent Var- } \\
\text { iables }\end{array}$} & \multicolumn{2}{|c|}{$\begin{array}{l}\text { Unstandardized } \\
\text { Coefficients }\end{array}$} & \multirow{2}{*}{$\begin{array}{c}\text { Standardized } \\
\text { Coefficients } \\
\text { B }\end{array}$} & \multirow[t]{2}{*}{$\mathrm{t}$} & \multirow[t]{2}{*}{ Sig. } & \multicolumn{2}{|c|}{$\begin{array}{c}\text { Collinearity Sta- } \\
\text { tistics }\end{array}$} \\
\hline & & $\beta$ & $\begin{array}{l}\text { Std. } \\
\text { Error }\end{array}$ & & & & Tolerance & VIF \\
\hline 1 & $\begin{array}{l}\text { (Constant) } \\
\text { Age } \\
\text { Gender } \\
\text { Tenure }\end{array}$ & $\begin{array}{l}4.01 \\
.00 \\
-.07 \\
-.03 \\
\end{array}$ & $\begin{array}{l}.34 \\
.01 \\
.13 \\
.03 \\
\end{array}$ & $\begin{array}{r}.00 \\
-.03 \\
-.11 \\
\end{array}$ & $\begin{array}{l}11.73 \\
-.00 \\
-.51 \\
-1.30 \\
\end{array}$ & $\begin{array}{l}.00 \\
1.00 \\
.61 \\
.19 \\
\end{array}$ & $\begin{array}{l}.54 \\
.99 \\
.54 \\
\end{array}$ & $\begin{array}{l}1.86 \\
1.01 \\
1.87 \\
\end{array}$ \\
\hline 2 & $\begin{array}{l}\text { (Constant) } \\
\text { Age } \\
\text { Gender } \\
\text { Tenure } \\
\text { ZAuthentic lead- } \\
\text { ership } \\
\text { ZLEE }\end{array}$ & $\begin{array}{l}.67 \\
.01 \\
.01 \\
-.01 \\
.65 \\
.15\end{array}$ & $\begin{array}{l}.33 \\
.01 \\
.08 \\
.02 \\
.08 \\
.06\end{array}$ & $\begin{array}{l}.06 \\
.01 \\
-.04 \\
.57 \\
.16\end{array}$ & $\begin{array}{l}2.05 \\
1.12 \\
.18 \\
-.76 \\
7.67 \\
\\
2.69\end{array}$ & $\begin{array}{l}.04 \\
.27 \\
.86 \\
.45 \\
.00 \\
\\
.00\end{array}$ & $\begin{array}{l}.54 \\
.97 \\
.53 \\
.25 \\
.41\end{array}$ & $\begin{array}{l}1.87 \\
1.03 \\
1.89 \\
3.98 \\
2.43\end{array}$ \\
\hline 3 & $\begin{array}{l}\text { (Constant) } \\
\text { Age } \\
\text { Gender } \\
\text { Tenure } \\
\text { ZAuthentic lead- } \\
\text { ership } \\
\text { ZLEE } \\
\text { ZAuthentic lead- } \\
\text { ership*ZLEE }\end{array}$ & $\begin{array}{c}3.70 \\
.01 \\
.01 \\
-.01 \\
.56 \\
\\
.15 \\
-.16\end{array}$ & $\begin{array}{l}.21 \\
.01 \\
.08 \\
.02 \\
.07 \\
\\
.06 \\
.05\end{array}$ & $\begin{array}{l}.06 \\
.01 \\
-.04 \\
.57 \\
\\
.16 \\
-.17\end{array}$ & $\begin{array}{c}17.85 \\
1.12 \\
.18 \\
.76 \\
7.67 \\
\\
2.69 \\
-3.12\end{array}$ & $\begin{array}{l}.00 \\
.27 \\
.86 \\
.45 \\
.00 \\
\\
.01 \\
.00\end{array}$ & $\begin{array}{l}.54 \\
.97 \\
.53 \\
.25\end{array}$ & $\begin{array}{l}1.87 \\
1.03 \\
1.89 \\
3.98 \\
\\
2.43 \\
2.11\end{array}$ \\
\hline
\end{tabular}

According to the above tables, leader emotional expressivity (LEE) $(\beta=-0.17, \mathrm{t}=-3.12, \mathrm{p}<$ $.05)$ moderates the relationship between authentic leadership and follower job satisfaction. While leader emotional expressivity has a positive contribution $(\beta=.16, t=2.69, \mathrm{p}<.05)$ to the dependent variable of job satisfaction, the interaction of leader emotional expressivity with authentic leadership is negative. The model explains $65 \%$ of the variance $(\mathrm{p}<.05)$ in the dependent variable. Therefore, $\mathrm{H} 2$ (The relationship between authentic leadership and follower job satisfaction will be moderated by leader emotional expressivity (LEE), in such a way that the relationship between authentic leadership and follower job satisfaction is more positive for those employees whose leaders are lower on LEE as compared to those whose leaders are higher on LEE) is supported.

Figure 2 below shows the moderation chart depicting the moderating effect of LEE on the relationship between authentic leadership and follower job satisfaction.

Figure 2 below suggests that the relationship between job satisfaction and authentic leadership are more positive for those employees whose leaders are lower on emotional expressivity (low LEE) as compared to those whose leaders are higher on emotional expressivity (high LEE). 
Baker, N. (2018). Authentic leadership and follower job satisfaction: The moderating effect of leader emotional expressivity. International Journal of Social Sciences and Education Research, 4(4), 689-697.

Figure 2. Moderation chart depicting the moderating effect of LEE on the relationship between authentic leadership and follower job satisfaction

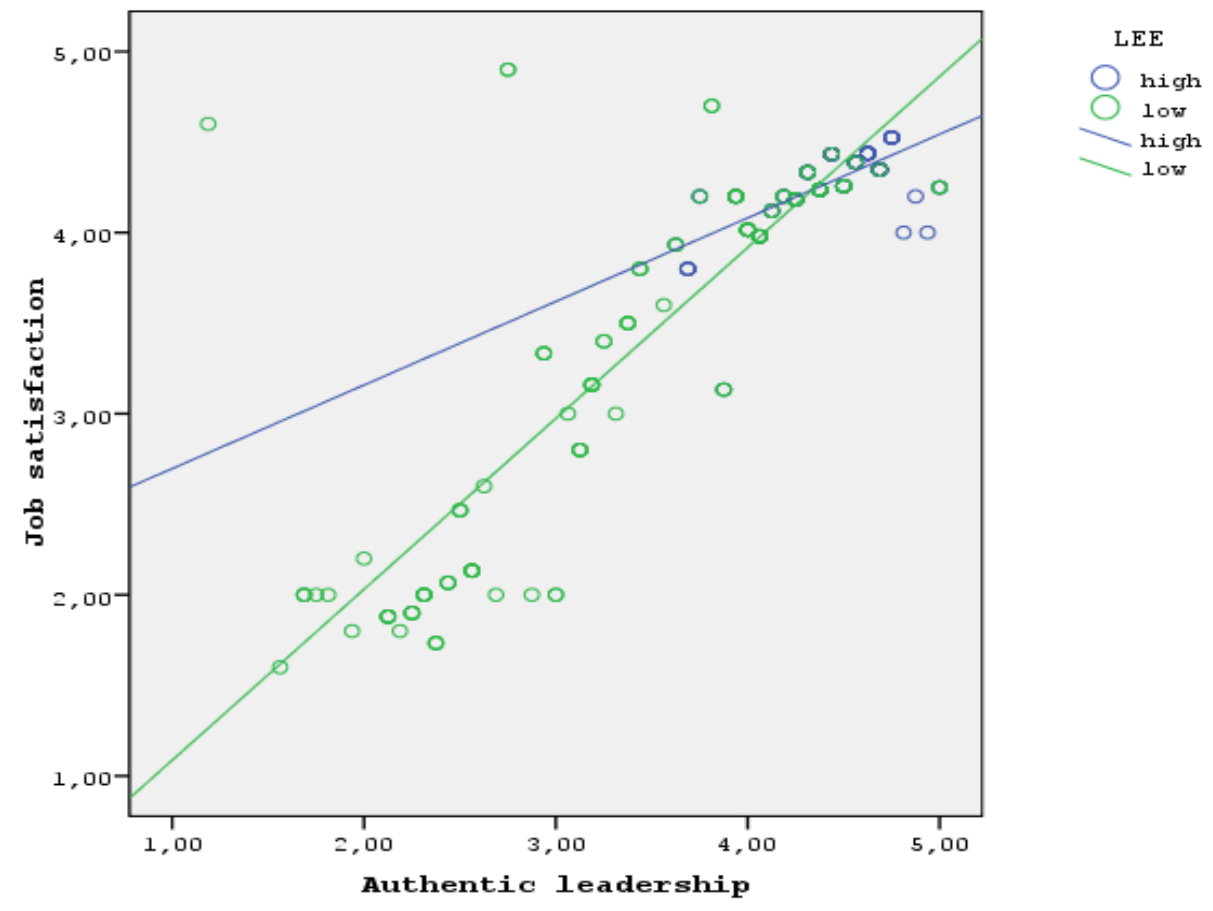

\section{Discussion and conclusion}

As hypothesized and found in H1, followers of authentic leaders enjoy greater job satisfaction. According to the definition of Henderson and Hoy (1983), authentic leaders demonstrate the acceptance of organizational and personal responsibility for actions, outcomes, and mistakes, and tend to be non-manipulating of subordinates. All these qualities of authentic leaders will elicit a greater job satisfaction from their immediate followers.

As hypothesized and found in $\mathrm{H} 2$, leader emotional expressivity (LEE) moderates the relationship between authentic leadership and follower job satisfaction. Although leader emotional expressivity has a significant positive contribution to follower job satisfaction; in line with our expectations, higher leader emotional expressivity weakens the positive contribution of authentic leadership to follower job satisfaction for leaders who are already strongly authentic. The findings indicate that leader emotional expressivity has a positive contribution to follower job satisfaction. Also, in line with our propositions, the strength of leader emotional expressivity weakened the contributions of authentic leadership on to follower job satisfaction for leaders who are highly authentic. Namely, if leaders are highly emotionally expressive and if they are at the same time strongly authentic, then the interaction of these two strong qualities results in weaker positive contribution of authentic leadership to follower job satisfaction. On the other hand, higher leader emotional expressivity compensates for the low levels of authenticity in terms of increasing follower job satisfaction.

The combination of very strong authenticity by the leader and being highly emotionally expressive may result in an overly-possessive kind of leader-follower relationship in the eyes of the followers, such as in case of an overly possessive relationship between adults and children, where adults have a wish to be fully in control of the situation and attempt to make sure that they will 
Baker, N. (2018). Authentic leadership and follower job satisfaction: The moderating effect of leader emotional expressivity. International Journal of Social Sciences and Education Research, 4(4), 689-697.

get their fair share of benefits from the relationship (Flasher, 1978). Such a view of the leader by the followers may contribute to the decrease in follower job satisfaction. Namely, followers may think that their leader is crossing a boundary with them by being highly emotionally expressive in addition to being strongly authentic.

The results of this study also highlight the fact that there can be a leader emotional expressivity premium, in such a way that leaders who are not strongly authentic, however, if they are highly emotionally expressive, this high level of emotional expressivity can compensate for their lack of authenticity. Therefore, followers may commit to a highly emotionally expressive leader even if this leader lacks authenticity. The existence of a high level of leader emotional expressivity can thus alter the charisma of the leader in parallel with the findings by Bono and Ilies (2006), where mood contagion, through the expression of positive emotions, was one of the psychological mechanisms by which charismatic leaders influence followers.

\section{Directions for future research}

This study does not explain the reason why the strength of leader emotional expressivity weakened the contribution of authentic leadership to follower job satisfaction for leaders who are highly authentic.

Therefore, we suggest that follower characteristics such as individualism or egalitarianism values can be studied in future research in order to be able to interpret the moderation of leader emotional expressivity better. We think that follower characteristics, which were beyond the scope of this research, can play a role in the negative moderating effect of leader emotional expressivity on the relationship between authentic leadership and follower job satisfaction. For example, followers, if they share an egalitarian point of view, might more strongly regard the highly emotionally expressive leader as crossing a boundary and become intimidated by that leader.

\section{References}

Avolio, B. J., \& Gardner, W. L. (2005). Authentic leadership development: Getting to the root of positive forms of leadership. The Leadership Quarterly, 16(3), 315-338.

Ayça, B. (2016). Otantik liderlik davranışının iş tatmini ve örgütsel bağlllı̆̆a etkisinin incelenmesi ve otel işletmelerinde bir araştırma (Doctoral thesis, Haliç Üniversitesi, Istanbul, Turkey). Retrieved from https://tez.yok.gov.tr/UlusalTezMerkezi/tezSorguSonucYeni.jsp

Bennis, W. (2003). On Becoming a Leader. Cambridge, MA: Perseus Publishing.

Brayfield, A., \& Rothe, H. (1951). An index of job satisfaction. Journal of Applied Psychology, 35(5), 307-311.

Cooper, C. D., Scandura, T. A. \& Schriesheim, C. A. (2005). Looking forward but learning from our past: Potential challenges to developing authentic leadership theory and authentic leaders. The Leadership Quarterly, 16(3), 475-493.

Eriksen, M. (2009). Authentic leadership: Practical reflexivity, self awareness, and self-authorship. Journal of Management Education, 33(6), 747-771.

Gardner, W. L., Avolio, B. J., Luthans, F., May, D. R., \& Walumbwa, F. (2005). Can you see the real me? A self based model of authentic leader and follower development. The Leadership Quarterly, 16(3), 343-372.

George, J. M. (2000). Emotions and leadership: The role of emotional intelligence. Human Relations, 53(8), 1027-1055. 
Baker, N. (2018). Authentic leadership and follower job satisfaction: The moderating effect of leader emotional expressivity. International Journal of Social Sciences and Education Research, 4(4), 689-697.

Gezer, A. (2015). Otantik liderlik davranışlarının iş tutumlarına etkisi: Mersin ili finans sektöründe bir saha araştırması (Master's thesis, Toros University, Mersin, Turkey). Retrieved fromhttp://openaccess.toros.edu.tr/bitstream/handle/123456789/64

Henderson, J. E., \& Hoy, W. K. (1983). Leader authenticity: The development and test of an operational measure. Educational and Psychological Research, 3(2), 63-75.

Ilies, R., Morgeson, F. P., \& Nahrgang, J. D. (2005). Authentic leadership and eudaemonic well-being: Understanding leader-follower outcomes. The Leadership Quarterly, 16(3), 373-394.

Judge, T. A., Locke, E. A., Durham, C., \& Kluger, A. N. (1998). Dispositional Effects on Job and Life Satisfaction: The Role of Core Evaluations. Journal of Applied Psychology, 83(1), 17-34.

Kring, A. M., Smith, D. A., \& Neale, J. M. (1994). Individual Differences in Dispositional Expressiveness: Development and Validation of the Emotional Expressivity Scale. Journal of Personality and Social Psychology, 66(5), 934-949.

Locke, E. A. (1976). The cause and nature of job satisfaction. In M.D. Dunnette (Ed.), Handbook of industrial and organizational psychology (pp. 1297-1349). Chicago, IL: Rand McNally.

Luthans, F., \& Avolio, B. J. (2003).Authentic leadership development. In K. S. Cameron, J. E. Dutton, \& R. E. Quinn (Eds.), Positive organizational scholarship: Foundations of a new discipline (pp. 241261). San Francisco: Barrett-Koehler.

Neider, L. L., Schriesheim, C. A. (2011). The authentic leadership inventory (ALI): Development and empirical tests. The Leadership Quarterly, 22(6), 1146-1164.

Peus, C., Wesche, J. S., Streicher, B., Braun, S. \& Frey, D. (2012). Authentic Leadership: An Empirical Test of Its Antecedents, Consequences, and Mediating Mechanisms. Journal of Business Ethics, 107(3), 331-348.

Rubin, R. S., Munz, D. C., \& Bommer, W. H. (2005). Leading from within: The effects of emotion recognition and personality on transformational leadership behavior. Academy of Management Journal, 48(5), 845-858.

Shamir, B., \& Eilam, G. (2005). What's your story? A life-stories approach to authentic leadership development. Leadership Quarterly, 16(3), 395-417.

Sparrowe, R. T. (2005). Authentic leadership and the narrative self. Leadership Quarterly, 16(3), 419439.

Sy, T., Côté, S., \& Saavedra, R. (2005). The contagious leader: Impact of the leader's mood on the mood of group members, group affective tone, and group processes. Journal of Applied Psychology, 90(2), 295-305.

Walumbwa, F. O., Avolio, B. J., Gardner, W. L., Wernsing, T. S., \& Peterson, S. J. (2008). Authentic leadership: Development and validation of a theory-based measure. Journal of Management, 34(1), 89-126.

Yukl, G. A. (2005). Leadership in organizations ( $\left.6^{\text {th }} e d.\right)$. New York: Prentice Hall. 